\title{
Earthquake-triggered landslides along the Hyblean-Malta Escarpment (off Augusta, eastern Sicily, Italy) - assessment of the related tsunamigenic potential
}

\author{
Maria Ausilia Paparo, Alberto Armigliato, Gianluca Pagnoni, Filippo Zaniboni, and Stefano Tinti \\ Department of Physics and Astronomy, University of Bologna, Bologna, Italy \\ Correspondence to: Maria Ausilia Paparo (mariaausilia.paparo2@unibo.it)
}

Received: 14 November 2016 - Accepted: 2 January 2017 - Published: 2 February 2017

\begin{abstract}
Eastern Sicily is affected by earthquakes and tsunamis of local and remote origin, which is known through numerous historical chronicles. Recent studies have put emphasis on the role of submarine landslides as the direct cause of the main local tsunamis, envisaging that earthquakes (in 1693 and 1908) did produce a tsunami, but also that they triggered mass failures that were able to generate an even larger tsunami. The debate is still open, and though no general consensus has been found among scientists so far, this research had the merit to attract attention on possible generation of tsunamis by landslides off Sicily. In this paper we investigate the tsunami potential of mass failures along one sector of the Hyblean-Malta Escarpment (HME). facing Augusta. The HME is the main offshore geological structure of the region running almost parallel to the coast, off eastern Sicily. Here, bottom morphology and slope steepness favour soil failures. In our work we study slope stability under seismic load along a number of HME transects by using the Minimun Lithostatic Deviation (MLD) method, which is based on the limit-equilibrium theory. The main goal is to identify sectors of the HME that could be unstable under the effect of realistic earthquakes. We estimate the possible landslide volume and use it as input for numerical codes to simulate the landslide motion and the consequent tsunami. This is an important step for the assessment of the tsunami hazard in eastern Sicily and for local tsunami mitigation policies. It is also important in view of tsunami warning system since it can help to identify the minimum earthquake magnitude capable of triggering destructive tsunamis induced by landslides, and therefore to set up appropriate knowledge-based criteria to launch alert to the population.
\end{abstract}

\section{Introduction}

Earthquakes and tsunamis have often affected Eastern Sicily (Fig. 1) and several of them are reported as disastrous in coeval chronicles (Burgos, 1693; Boccone, 1697; Mongitore, 1743). One example of such occurrences is the 11 January 1693 earthquake (hereafter referred to as E1693). It is the most important and largest seismic event for Sicily and indeed for the whole Italy $\left(M_{\mathrm{w}}=7.3\right.$; Rovida et al., 2016). Together with a concomitant tsunami (hereafter referred to as T1693), it caused destruction in numerous cities and villages, such as Siracusa, Catania, Augusta and Ragusa, for a total toll of about 60000 victims.

Today we know that there are several processes capable of generating tsunamis in addition to a seismic event, such as subaerial and submarine landslides, volcanic eruptions, oceanic meteorite/asteroid impacts and that, in some cases, tsunamis are generated by multiple factors acting together (NOAA, 2016). The mechanism of E1693 is still matter of debate. Some authors define an onshore seismic source (DISS Working Group, 2015), that however cannot justify the earthquake magnitude and the observed tsunami (Tinti and Armigliato, 2003). Others place the source offshore (Argnani and Bonazzi, 2005), hypothesis validated by the intensity distribution and by the tsunami. Argnani et al. (2012) assume that the E1693 source was located offshore, and speculate that, in addition to an earthquake-induced tsunami, an offshore landslide could have acted as a tsunamigenic source. The slide (about $5 \mathrm{~km}^{3}$ ) was identified on processing seismic surveys data at a depth of $2000 \mathrm{~m}$ below sea level. Simulation of the landslide motion and of the resulting tsunami (see details in Argnani et al., 2012), lead to tsunami waves inconsistent with the historical observations. In this work, insisting 


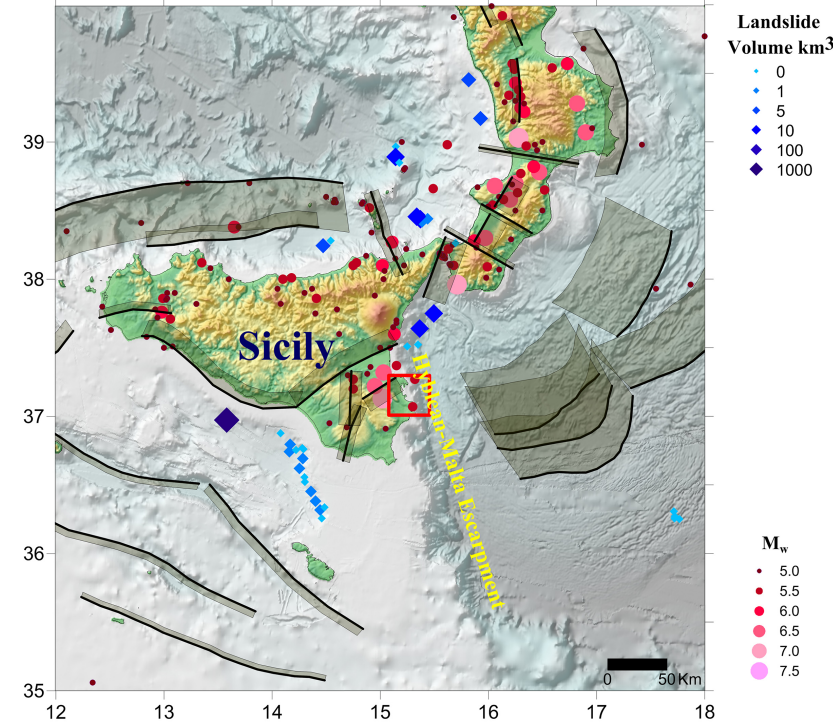

Figure 1. Map of the Sicily and southern Calabria with seismotectonic faults (shaded areas, Basili et al., 2013), historical $M_{\mathrm{W}}>5$ earthquakes (dots, Grünthal and Wahlström, 2012; Stucchi et al., 2012) and landslides (diamonds, Urgeles and Camerlenghi, 2013). The red rectangle outlines our study area.

on the idea of a tsunamigenic submarine mass movement, we investigate mass flows down the Hyblean-Malta Escarpment (HME) as potential sources of T1693. The fact that specific deposits of these submarine flows have been not identified in marine geological surveys so far is not a proof they did not occur, since the failed material could have been dispersed as a turbulent flow over very thin sheets, and later transported by deep sea currents and mixed with the seafloor sands. In this paper we focus on the Augusta Bay coast (red square in Figs. 1 and 2) where the most severe tsunami effects were observed. Our aims are (i) to examine the stability conditions of the HME segment facing Augusta and to estimate the Peak Ground Accelerations (PGAs) congruent with E1693 that could have induced a mass flow, (ii) in case of instability, to simulate the submarine landslide motion and the associated tsunami and (iii) to compare the tsunami simulation results with the observed effects of the T1693. Understanding all likely causes of the disastrous E1693 and T1693 is necessary in order to develop and implement proper mitigation policies for protecting people, facilities and environment in case of occurrence of a similar earthquake. It is worth mentioning that today the Augusta Bay region is densely inhabited with about 150000 people that triple during the touristic season, and that it hosts some of the biggest petrochemical industries of Europe, namely Esso Italiana S.r.l., Polimeri Europa S.p.A. (ex EniChem S.p.A.), Syndial S.p.A and LUKoil (ex. ERG).

This work is also a contribution to assess the tsunami hazard in eastern Sicily because it shows that restricting the attention only to tsunamis of seismic origin might be insuffi-

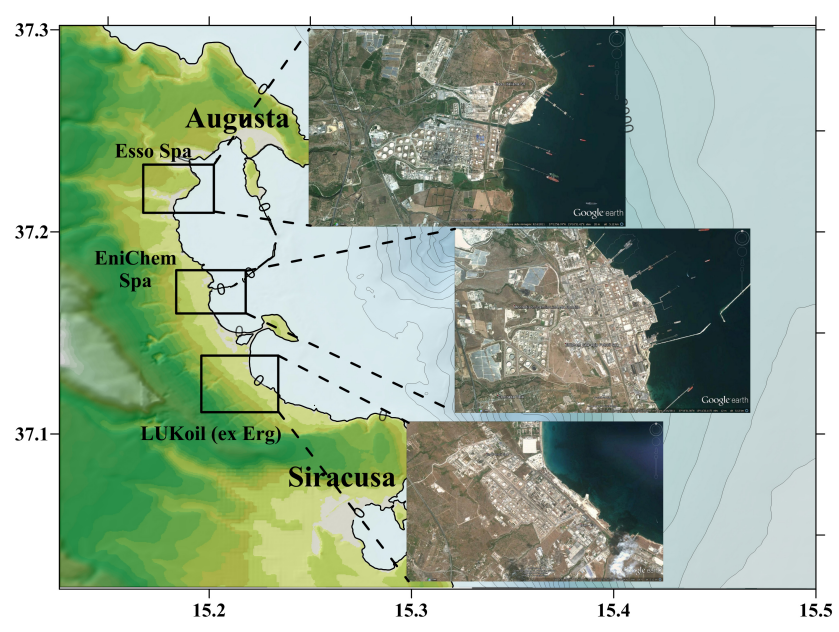

Figure 2. Sicilian coast between Augusta and Siracusa cities (red square of Fig. 1). The black squares identify the industrial areas of Esso SpA, EniChem SpA and LUKoil: satellite images from Google Earth.

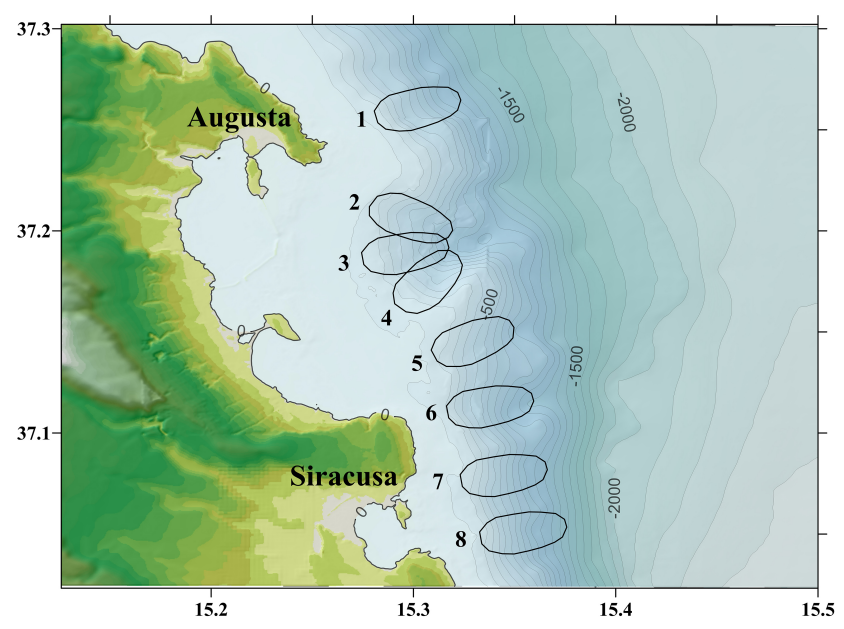

Figure 3. The oval areas outline roughly the footprints of the eight hypothetical landslides.

cient for those areas that could be affected also by tsunamis produced by earthquake-induced landslides.

\section{Geological setting}

The Augusta-Siracusa region is located in the NW corner of the Hyblean Plateau (HP), that is the NW uplifted shelf of the Pelagian platform, composed by carbonates layers with intercalated volcanic rocks (Torelli et al., 1998; Sirovich and Pettenati, 1999; Argnani et al., 2002; Argnani and Bonazzi, 2005; Micarelli et al., 2006). In parallel to the coastline of SE Sicily, the HME, with a length greater than $300 \mathrm{~km}$, outlines the eastern edge of the HP, separating the continental crust, about $23 \mathrm{~km}$ thick, from the oceanic crust of the Ionian Sea, about $11 \mathrm{~km}$ (Torelli et al., 1998). Underwater deep val- 


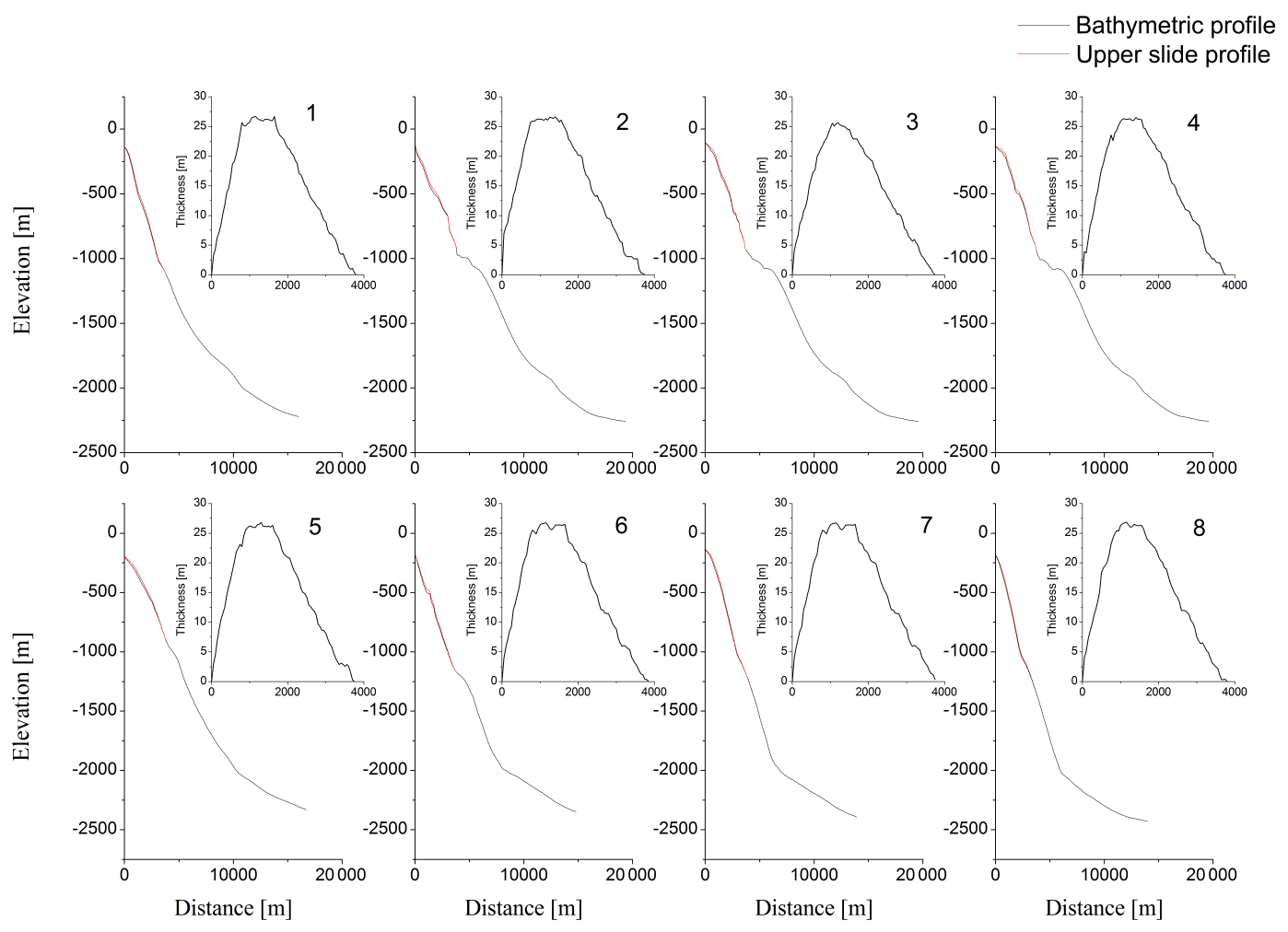

Figure 4. Bathymetric profiles and thicknesses.

leys and canyons characterize the cliff morphology. In some areas, the slope reaches a value greater than $20^{\circ}$, making it an area inclined to local instability. Dense seismic profiles have shown that, onshore and offshore, the region is characterized by three main well-defined sediment layers and a complex system of faults (Argnani et al., 2002) where the E1693 hypocentre could be well accomodated. The three layers are, (i) the Mesozoic carbonate sediment, (ii) the Cenozoic basin sediments and (iii) the Plio-Quaternary sediments (Argnani and Bonazzi, 2005; Micallef et al., 2014). The last layer composes the seafloor and we assume that the sliding mass could have involved only sediments of the Quaternary Period.

In our analysis, we have identified eight HME longitudinal sections in the Augusta Bay region from which the flow mass could have detached (Fig. 3). We use a fixed volume of about $77 \mathrm{Mm}^{3}$ and we have model the slide shape in dependence of the local slope morphology. On average, slide thickness reaches at most ca $25 \mathrm{~m}$ and its length is about $4000 \mathrm{~m}$ (Fig. 4). Typically here, the soil is composed of a sequence of layers made of basalt, pyroclastic rock, sand, gravel, clay and different pelagic sediments (Torelli et al., 1998). In general, the cohesion for this type of sediment structures can be considered very small or null, while the friction angle is reasonably comprised between 35 and $45^{\circ}$.

\section{Analysis and results}

Our work can be synthetized in three main steps: (i) the stability analysis of the HME profiles, (ii) the simulation of the mass movement and (iii) the tsunami propagation modelling. In each step we use specific in-house Fortran codes applied in several works (see Tinti et al., 2006, 2008; Zaniboni et al., 2013; Paparo et al., 2013; Zaniboni and Tinti, 2014): the EqLiMLD code evaluates the slope stability conditions, the UBO-BLOCK1 code simulates the landslide motion and the UBO-TSUFD code models the tsunami genesis and the tsunami propagation.

\subsection{Stability analysis of the HME slopes off Augusta Bay}

The EqLiMDL code, developed by Tinti and Manucci (2006, 2008) and modified by Paparo et al. (2013), has the aim to establish the equilibrium state of a given slope cross-section under specified conditions using the Minimum Lithostatic Deviation (MLD) method, that is a variant of the Limit Equilibrium (LE) method. The cross-section is divided into vertical slices and for each slice vertical and horizontal forces and torques are computed, taking into account all possible contributions including gravity, the seismic load in terms of peak ground acceleration and the water load of the sea. The LE method is simple, efficient, and widely used. It computes 


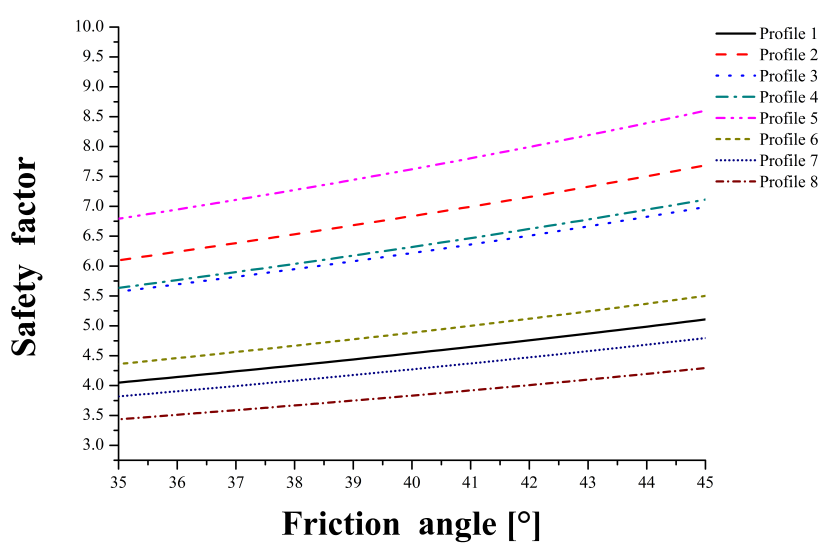

Figure 5. Safety Factor vs. friction angle for all profiles in noseismic condition. All profiles are stable, which means that Augusta HME is not prone to mass failure in absence of earthquakes.

the Safety Factor $(F)$, that is the ratio between the limit shear strength and the shear stress at the trial slide surface, whose value indicates whether a slide is in equilibrium or not: if $F$ is smaller than one, then the mass is prone to slide downslope, while if it is greater than one, it is stable and will not move. The MLD method introduces the lithostatic deviation parameter $\delta$ representing the average magnitude of the interslice forces normalized to the weight of the sliding mass. In virtue of the MLD principle, given a range of $F$ values, the EqLiMLD code takes the one minimizing $\delta$ as the $F$ representing the stability condition of the slope (further details in Tinti and Manucci, 2006, 2008; Paparo et al., 2013). Figure 5 shows the $F$ analysis results in no-seismic condition, varying the friction angle: all eight cross-sections turn out to be stable, which confirm their equilibrium before the E1693 event.

Introducing a seismic load, we have analyzed the HME profiles with a PGA ranging in the interval [0-1]g. The Augusta-Siracusa area is classified into the third seismic zone of the Italian seismic hazard map (Gruppo di Lavoro MPS, 2004): in this zone the (10\% exceedance probability in 50 years) PGA on bedrock is estimated to range from 0.12 to $0.25 \mathrm{~g}$ (see the violet box in Fig. 6a-c). Assuming these PGA values, all profiles happen to be stable. However, if one considers the macroseismic field of E1693 and makes use of a proper PGA-I regression relationship, one can estimate the PGA values of E1693 in the area off Augusta where the slides are supposedly located. In literature there are several regression laws computed for the Italian territory (see Chiaruttini and Siro, 1981; Margottini et al., 1992; Decanini et al., 1995; Faccioli and Cauzzi, 2006; Faenza and Michelini, 2010; Caprio et al., 2015). If we use the relation computed recently by Paparo and Tinti (2017), one sees that in correspondence of an MCS intensity XI, the PGA is $0.51 \mathrm{~g}$, much larger than the value associated with the third seismic zone. In the Fig. 6a-c, the dotted black line indicate the PGA $=0.511 \mathrm{~g}$ and the grey areas outline the un-
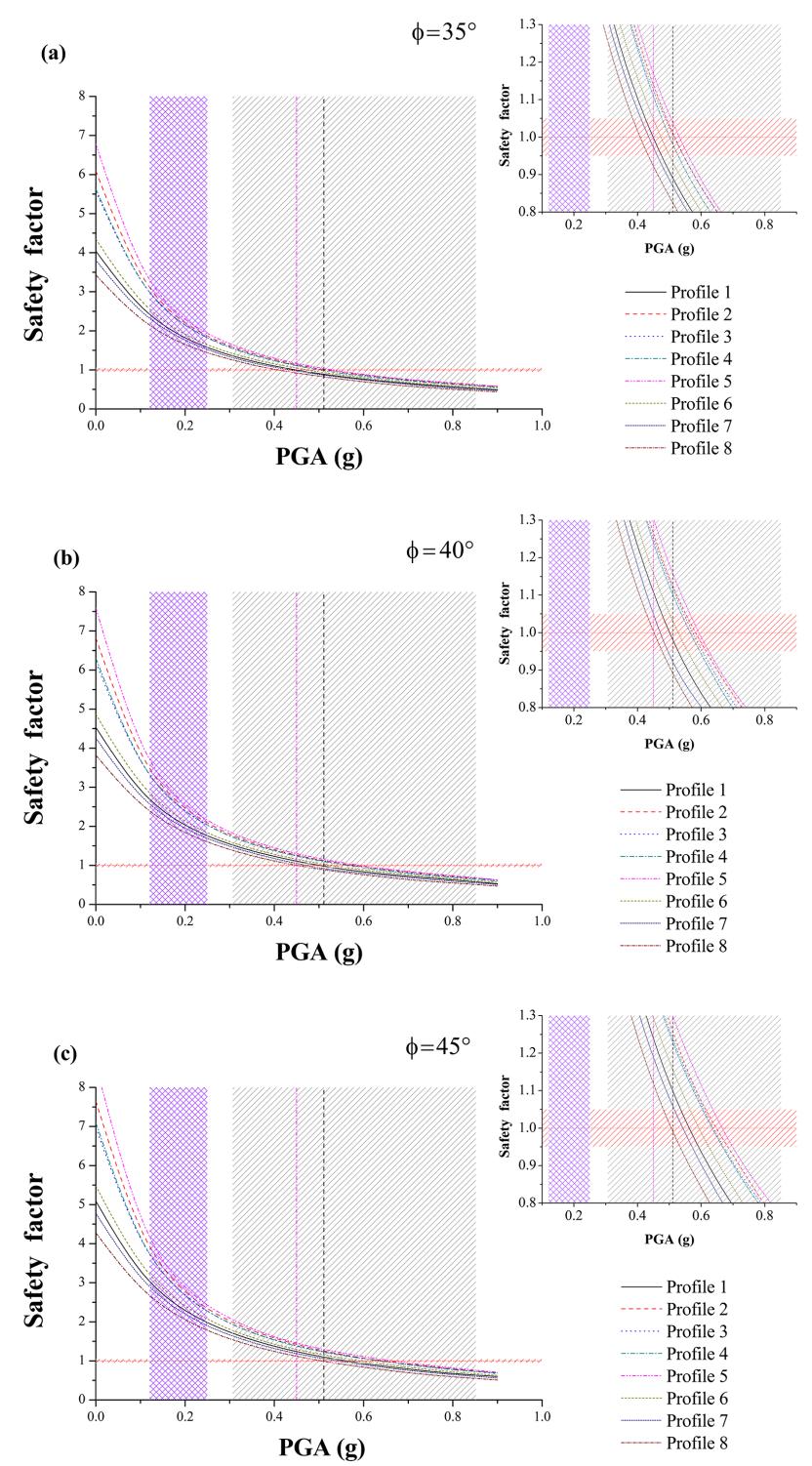

Figure 6. Safety Factor curves vs. PGA. The stability analysis is conducted for sediments with an average friction angle of $35^{\circ}$ (a), $40^{\circ}$ (b) and $45^{\circ}$ (c). Dotted horizontal red lines highlight the critical value $F=1$. Dotted vertical black lines indicate the $\mathrm{PGA}=0.511 \mathrm{~g}$ corresponding to IMCS $=\mathrm{XI}$ for the regression relationship PGAIMCS by Paparo and Tinti (2017). Grey areas mark the uncertainty band associated with the estimated PGA value. Purple areas mark the PGA interval of the Italian seismic hazard maps, built using the 16th, 50th and 84th percentiles of the PGA distribution with $10 \%$ probability of exceedance in 50 years (Gruppo di Lavoro MPS, 2004).

certainty band associated with the PGA value: under these seismic loads, all profiles could reach unstable conditions, which confirms the hypothesis that the 1693 earthquake can have induce landslides on the steep slopes of the HME, off the coasts of Augusta Bay. 


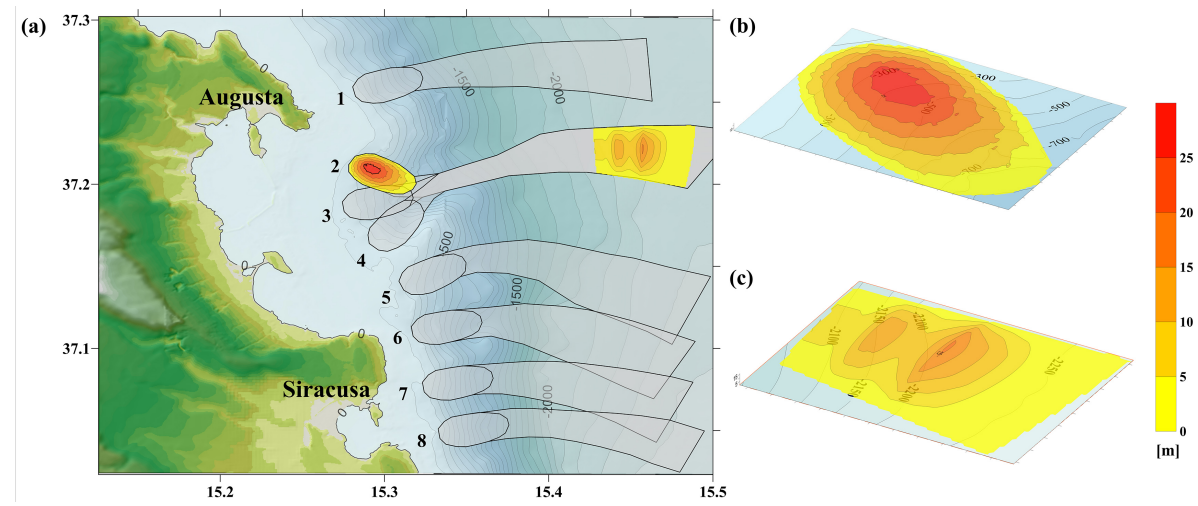

Figure 7. (a) Black contours mark the respective sliding surface boundary for the assumed landslide scenario. (b) 3-D shape of the initial slide body. (c) Example of final simulated deposit.

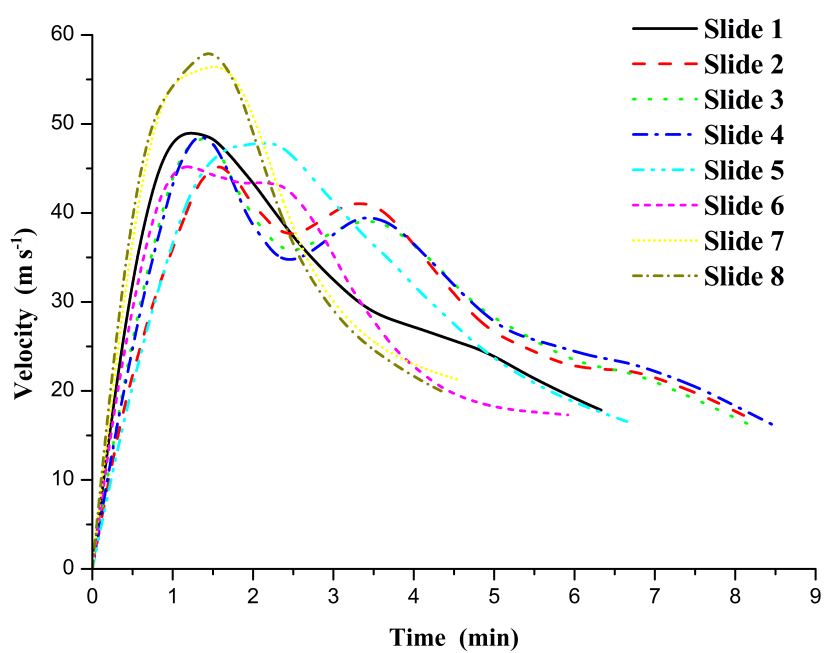

Figure 8. Average-over-block velocity for each of the eight simulated landslides.

\subsection{Simulation of the landslides}

Verified that the soil could break along a given trial surface under opportune conditions, the code UBO-BLOCK1, developed by the University of Bologna Tsunami Research Team, simulates the landslide motion through a Lagrangian approach. The mass is simplified as a chain of blocks and the code computes the motion of the centre of mass (CoM) of the blocks that move along a predefined path (Fig. 7) wing to the action of body forces (gravity and buoyancy), the bottom friction, the frontal drag and the block-block interactions. The sliding mass moves the water around, providing the impulse for the tsunami generation. Using an intermediate algorithm, we evaluate the impulse transmitted by the moving mass to the water surface (further details in Tinti et al., 1997). The slide velocity (averaged over the blocks) is shown for all scenarios in Fig. 8, from where one can see that the peak velocities range between 45 to $60 \mathrm{~m} \mathrm{~s}^{-1}$ and are attained in the first 60-90 s.

\subsection{Tsunami simulation}

Using the sliding mass as a perturbative term, the UBOTSUFD code, developed by the Tsunami Research Team of the University of Bologna, simulates the tsunami generation and propagation, solving the incompressible NavierStokes equations in the non-linear inviscid non-dispersive shallow-water approximation. The code implements a finitedifference numerical scheme over a structured grid composed by equally spaced nodes (Tinti and Tonini, 2013). Figure 9 shows that all potential landslides are able to generate a sizable tsunami with waves at least $1 \mathrm{~m}$ high. In scenarios 3 , 4 and 5 the sea reaches a level up to $5 \mathrm{~m}$ in the Augusta area, while in scenarios 2, 3 and 7 we find a similar situation for the Magnisi peninsula.

\section{Conclusions}

Eastern Sicily is often hit by earthquakes and tsunamis. The 11 January 1693 earthquake was the strongest of the seismic history of Italy. In this work, we have explored the hypothesis that the earthquake generated a tsunamigenic landslide. We have selected eight profiles of the Hyblean-Malta Escarpment in the segment facing the Augusta Bay and have analyzed their equilibrium conditions under seismic load. After estimating a PGA value larger than $0.5 \mathrm{~g}$ congruent with the E1693 intensity field, the stability analysis shows that the HME slope could be destabilized by E1693 and, due to its steepness, fast landslides could have taken place. All simulated landslides reach deep sea (over $2000 \mathrm{~m}$ b.s.l.) in few minutes, after a strong acceleration phase, leading to peak velocities of $45-60 \mathrm{~m} \mathrm{~s}^{-1}$, depending on the escarpment morphology. The landslide motion is the input for tsunami waves in the area between Augusta and Siracusa: in our simulations in some scenarios, their height is at least $1 \mathrm{~m}$ and in some 


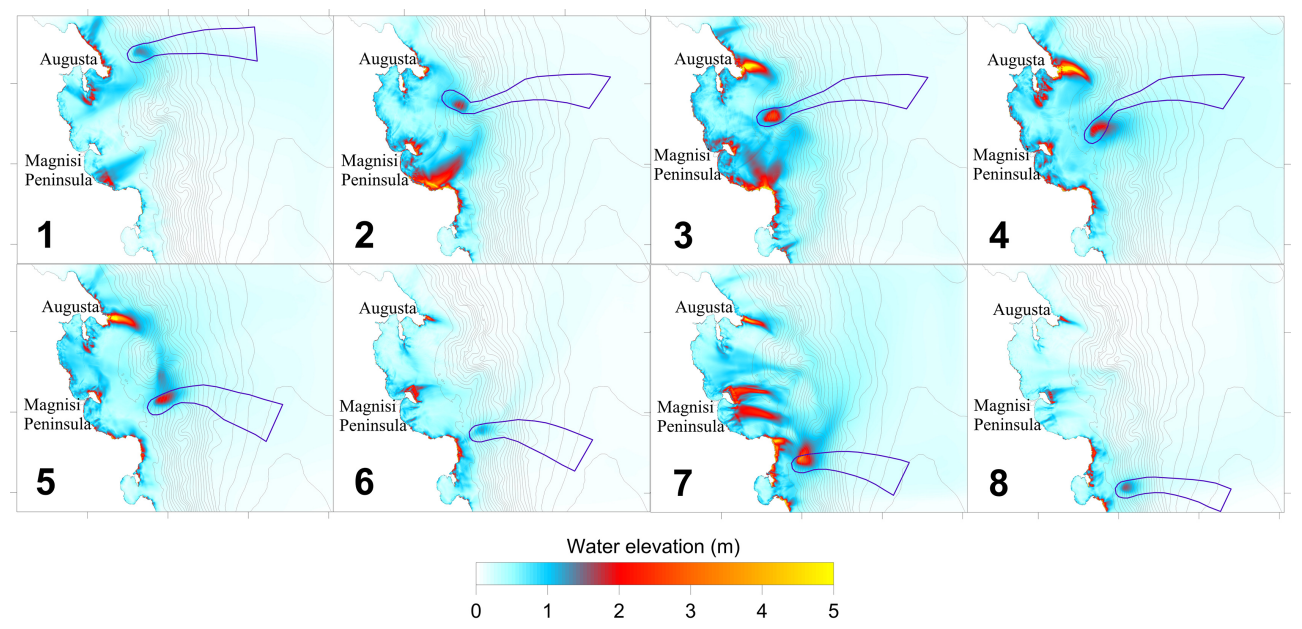

Figure 9. All landslides scenarios show tsunami waves at least $1 \mathrm{~m}$ high. In scenarios 3,4 and 5 the sea reaches a level up to $5 \mathrm{~m}$ to the north-west of Augusta; similar, in scenarios 2, 3, 7 for the Magnisi peninsula. The violet contours mark the sliding surface boundaries.

areas the local maxima are over $8 \mathrm{~m}$, following historical reports. In this work we demonstrated that in the region of $\mathrm{Au}$ gusta, Eastern Sicily, large earthquakes can trigger tsunamigenic landslides that can add disaster to the damage produced by seismic shaking. Our study can be seen as a preliminary contribution to the hazard assessment of Eastern Sicily.

\section{Data availability}

Bathymetry and topography data used to draw Figs. 1-3 were taken from the publicly available GEBCO database (General Bathymetric Chart of the Oceans, http://www.gebco.net/). In Fig. 1, historical earthquake data are from Grünthal and Wahlström (2012) (http://www.gfz-potsdam.de/en/section/ seismic-hazard-and-stress-field/data-products-services/ emec-earthquake-catalogue/) and Stucchi et al. (2012) (http://www.emidius.eu/SHEEC/sheec_1000_1899.html); landslide deposits are taken from Urgeles and Camerlenghi (2013); seismogenic sources are taken from the SHARE-EDSF database (Basili et al., 2013 http://diss.rm.ingv.it/share-edsf/)

Acknowledgements. This work was carried out in the frame of the EU Project called ASTARTE - Assessment, STrategy And Risk Reduction for Tsunamis in Europe (Grant 603839, 7th FP, ENV.2013.6.4-3). We like to thank the two reviewers, Efim Pelinovsky and Gerassimos Papadopoulos for their helpful suggestions as well as the Topical Editor Giuseppe Tito Aronica for his support.

Edited by: G. T. Aronica

Reviewed by: E. Pelinovsky and G. Papadopoulos

\section{References}

Argnani, A. and Bonazzi, C.: Malta Escarpment fault zone offshore eastern Sicily: Pliocene-Quaternary tectonic evolution based on new multichannel seismic data, Tectonics, 24, TC4009, doi:10.1029/204TC001656, 2005.

Argnani, A., Bonazzi, C., and MESC 2001 CREW: Tectonics of eastern Sicily offshore: preliminary results from the MESC 2001 marine seismic cruise, B. Geofis. Teor. Appl., 43, 177-193, 2002.

Argnani, A., Armigliato, A., Pagnoni, G., Zaniboni, F., Tinti, S., and Bonazzi, C.: Active tectonics along the submarine slope of south-eastern Sicily and the source of the 11 January 1693 earthquake and tsunami, Nat. Hazards Earth Syst. Sci., 12, 13111319, doi:10.5194/nhess-12-1311-2012, 2012.

Basili, R., Kastelic, V., Demircioglu, M. B., Garcia Moreno, D., Nemser, E. S., Petricca, P., Sboras, S. P., Besana-Ostman, G. M., Cabral, J., Camelbeeck, T., Caputo, R., Danciu, L., Domac, H., Fonseca, J., García-Mayordomo, J., Giardini, D., Glavatovic, B., Gulen, L., Ince, Y., Pavlides, S., Sesetyan, K., Tarabusi, G., Tiberti, M. M., Utkucu, M., Valensise, G., Vanneste, K., Vilanova, S., and Wössner, J.: The European Database of Seismogenic Faults (EDSF) compiled in the framework of the Project SHARE, doi:10.6092/INGV.IT-SHARE-EDSF, 2013.

Boccone, P.: Intorno il terremoto della Sicilia seguito l'anno 1693 , Museo di Fisica, Venezia, IT, 1-31, 1697.

Burgos, A.: Distinta relazione avuta per lettera del P. Alessandro Burgos scritta ad un suo amico, che contiene le notizie fin'ora avute de' danni cagionati in Sicilia da terremoti a 9 e 11 gennaio 1693, Palermo-Roma, 1693.

Caprio, M., Tarigan, B., Worden, C. B., Wiemer, S., and Wald, D. J.: Ground Motion to Intensity Conversion Equations (GMICEs): A Global Relationship and Evaluation of Regional Dependency, B. Seismol. Soc. Am., 105, 1476-1490, doi:10.1785/0120140286, 2015.

Chiaruttini, C. and Siro, L.: Focal mechanism of an earthquake of Baroque Age in the Regno delle Due Sicilie (southern Italy), in: "Investigation of Historical Earthquakes in Europe", edited by: 
Stucchi, M., Postpischl, D., and Slejko, D., Tectonophysics, 193, 195-203, 1981.

Decanini, L., Gavarini, C., and Mollaioli, F.: Proposta di definizione delle relazioni tra intensità macrosismica e parametri del moto del suolo, in Atti del 7 Convegno Nazionale Ingegneria sismica in Italia, 1, 63-72, 1995.

DISS Working Group: Database of Individual Seismogenic Sources (DISS), Version 3.2.0: A compilation of potential sources for earthquakes larger than $M 5.5$ in Italy and surrounding areas, Istituto Nazionale di Geofisica e Vulcanologia, http://diss.rm.ingv. it/diss/, doi::10.6092/INGV.IT-DISS3.2.0, 2015.

Faccioli, E. and Cauzzi, C.: Macroseismic intensities for seismic scenarios estimated from instrumentally based correlations, Proceedings of the 1st European Conference on Earthquake Engineering and Seismology, No. 569, 2006.

Faenza, L. and Michelini, A.: Regression analysis of MCS intensity and ground motion parameters in Italy and its application in ShakeMap, Geophys. J. Int., 180, 1138-1152, doi:10.1111/j.1365-246X.2009.04467.x, 2010.

Gerardi F., Barbano M. S., De Martino P. M., and Pantosti D.: Discrimination of Tsunami sources (Earthquake versus Landslide) on the basis of historical data in Eastern Sicily and Southern Calabria, B. Seismol. Soc. Am., 98, 2795-2805, 2008.

Grünthal, G. and Wahlström, R.: The European-Mediterranean Earthquake Catalogue (EMEC) for the last millennium, J. Seismol., 16, 535-570, doi:10.1007/s10950-012-9302-y, 2012.

Gruppo di Lavoro MPS: Redazione della mappa di pericolosità sismica prevista dall'Ordinanza PCM 3274 del 20 marzo 2003, Rapporto Conclusivo per il Dipartimento della Protezione Civile, INGV, Milano-Roma, aprile 2004, 65, 2004.

Gutscher M. A., Roger, J., Baptista, M. A., Miranda, J. M., and Tinti, S.: Source of the 1693 Catania earthquake and tsunami (southern Italy): New evidence from tsunami modeling of a locked subduction fault plane, Geophys. Res. Lett., 33, L08309, doi:10.1029/2005GL025442, 2006.

Margottini, C., Molin, D., and Serva, L.: Intensity versus ground motion: A new approach using Italian data, Eng. Geol. 33, 4558, 1992.

Micallef, A., Georgiopoulou, A., Le Bas, T., Mountjoy, J. J., Huvenne, V., and Lo Iacono, C.: The Malta-Sicily Escarpment: Mass Movement dynamics in a sediment-undersupplied margin, edited by: Krastel et al. (Eds.), Submarine Mass Movements and Their Consequences, Switzerland, Springer International Publishing, 37, 317-328, 2014.

Micarelli, L., Benedicto, A., and Wibberley, C. A. J.: Structural evolution and permeability of normal fault zones in highly porous carbonate rocks, J. Struct. Geol., 28, 1214-1227, 2006.

Mongitore, A.: Istoria cronologica de' terremoti di Sicilia, in: Della Sicilia ricercata nelle cose più memorabili, Palermo, IT, Vol. 2, 1743.

Murphy, J. R. and O'Brien, L. J.: The correlation of peak ground acceleration amplitude with seismic intensity and other physical parameters, B. Seismol. Soc. Am., 67, 877-915, 1977.

NOAA: National Geophysical Data Center/World Data Service (NGDC/WDS), Global Historical Tsunami Database, National Geophysical Data Center, NOAA, doi:10.7289/V5PN93H7, 2016.
Paparo, M. A. and Tinti, S.: Analysis of seismic-driven instability of Mt. Nuovo in the Ischia island, Italy, Bull. Seism. Soc. Am., 107, doi:10.1785/0120160139, in press, 2017.

Paparo, M. A., Zaniboni, F., and Tinti, S.: The Vajont landslide, 9th october 1963: limit equilibrium model for slope stability analysis through the minimum lithostatic deviation method, Ital. J. Eng. Geol. Environ., 6, 583-592, 2013.

Rovida, A., Locati, M., Camassi, R., Lolli, B., and Gasperini, P.: CPTI15, the 2015 version of the Parametric Catalogue of Italian Earthquakes, Istituto Nazionale di Geofisica e Vulcanologia, doi:10.6092/INGV.IT-CPTI15, 2016.

Sirovich, L. and Pettenati, F.: Seismic outline of South-Eastern Sicily: an evaluation of available options for the earthquake fault rupture scenario, J. Seismol., 3, 213-233, 1999.

Stucchi M., Rovida, A., Gomez Capera, A. A., Alexandre, P., Camelbeeck, T., Demircioglu, M. B., Gasperini, P., Kouskouna, V., Musson, R. M. W., Radulian, M., Sesetyan, K., Vilanova, S., Baumont, D., Bungum, H., Faeh, D., Lenhardt, W., Makropoulos, K., Martinez Solares, J. M., Scotti, O., Živčić, M., Albini, P., Batllo, J., Papaioannou, C., Tatevossian, R., Locati, M., Meletti, C., Viganò, D., and Giardini, D.: The SHARE European Earthquake Catalogue (SHEEC) 1000-1899, J. Seismol., 17, 523-544, doi:10.1007/s10950-012-9335-2, 2012.

Tinti, S. and Armigliato, A.: The use of scenarios to evaluate the tsunami impact in southern Italy, Mar. Geol., 199, 221-243, doi:10.1016/S0025-3227(03)00192-0, 2003.

Tinti, S. and Manucci, A.: Gravitational stability computed through the limit equilibrium method revisited, Geophys. Int. J., 164, 1$14,2006$.

Tinti, S. and Manucci, A.: A new computational method based on the minimum lithostatic deviation (MLD) principle to analyse slope stability in the frame of the 2-D limit-equilibrium theory, Nat. Hazards Earth Syst. Sci., 8, 671-683, doi:10.5194/nhess-8671-2008, 2008.

Tinti, S. and Tonini, R.: The UBO-TSUFD tsunami inundation model: validation and application to a tsunami case study focused on the city of Catania, Italy, Nat. Hazards Earth Syst. Sci., 13, 1795-1816, doi:10.5194/nhess-13-1795-2013, 2013

Tinti, S., Bortolucci, E., and Vannini, C.: A block-based theoretical model suited to gravitational sliding, Nat. Hazards, 16, 1-28 doi:10.1023/A:1007934804464, 1997.

Tinti S., Zaniboni, F., and Pagnoni, G.: The landslides and tsunamis of the 30th December 2002 in Stromboli abalysed through numerical simulations, B. Volcanol., 68, 462-479, 2006.

Tinti S., Zaniboni, F., Pagnoni, G., and Manucci, A.: Stromboli Island (Italy): scenarios of tsunamis generated by submarine landslides, Pure Appl. Geophys., 165, 2143-2167, doi:10.1007/s00024-008-0420-y, 2008.

Torelli, L., Grasso M., Mazzoldi G., and Peis D.: Plio-Quaternary tectonic evolution and structure of the Catania foredeep, the northern Hyblean Plateau and the Ionian shelf (SE Sicily), Tectonophysics, 298, 209-221, 1998.

Trifunac, M. D. and Brady, A. G.: On the correlation of seismic intensity scales with the peaks of recorded strong ground motion, B. Seismol. Soc. Am., 65, 139-162, 1975.

Urgeles, R. and Camerlenghi, A.: Submarine landslides of the Mediterranean Sea: Trigger mechanism, dynamics, and frequency-magnitude distribution, J. Geophys. Res., 118, 26002618, doi:10.1002/2013JF002720, 2013. 
Zaniboni, F. and Tinti, S.: Numerical simulations of the 1963 Vajont Landslide, Italy: Application of 1D Lagrangian Modelling, Nat. Hazards, 70, 567-592, 2014.
Zaniboni, F., Paparo, M. A., and Tinti, S.: The 1963 Vajont landslide analysed through numerical modeling, Ital. J. Eng. Geol. Environ., 6, 623-632, 2013. 